\title{
ANALISIS PENERAPAN AKUNTANSI LINGKUNGAN DALAM PENGELOLAAN LIMBAH DAN TANGGUNG JAWAB SOSIAL PADA RUMAH SAKIT STROKE NASIONAL BUKITTINGGI
}

\author{
Angga Kusuma, Rina Asmeri, SE, M.SI, Nova Begawati, SE.MM \\ Fakultas Ekonomi Universitas Ekasakti Padang \\ JL. Veteran Dalam No. 26B Padang Barat. Kota Padang. Sumatera Barat 25113
}

ABSTRACK

In the service process of Bukittinggi National Stroke Hospital has the potential to generate waste. The waste generated by the National Stroke Hospital of Bukittinggi is medical waste in the form of solid waste and liquid waste. In the sewage treatment the National Stroke Hospital of Bukittinggi has an Incenerator that is used for waste combustion. As for the liquid waste treatment of Bukittinggi National Stroke Hospital has WWTP (Waste Water Treatment Installation). Waste generated must be managed properly so as not to cause negative impact for patients, visitors, employees, and the surrounding community. The purpose of this study is to Apply Environmental Accounting Analysis in Waste Management and Social Responsibility at Bukittinggi National Stroke Hospital. This research is a qualitative research. Data collection techniques are interviews and documentation and data used are primary and secondary data. The findings of the National Hospital of Stroke Bukittinggi have made the process of Identification, Recognition, Measurement, Recording, Presentation, and Disclosure as well as those described in Government Accounting Standards as of June 13, 2010. SAP No. 1 describes the presentation of financial statements. Where is the National Hospital of Bukittinggi Stroke. National Hospital of Stroke Bukittinggi has done their waste management well. Bukit Tinggi Stroke National Hospital which has already spent its environmental expenses

Keywords: Acconting enviromet

\begin{abstract}
ABSTRAK
Dalam proses pelayanan jasa Rumah Sakit Stroke Nasional Bukittinggi berpotensi menghasilkan limbah. Limbah yang dihasilkan oleh Rumah Sakit Stroke Nasional Bukittinggi adalah limbah medis berupa limbah padat dan limbah cair. Dalam Pengelolahan limbah tersebut Rumah Sakit Stroke Nasional Bukittinggi memiliki Incenerator yang digunakan untuk pembakaran limbah. Sedangkan untuk pengelolahan limbah cair Rumah Sakit Stroke Nasional Bukittinggi memiliki IPAL ( Instalasi Pengelolahan Air Limbah ). Limbah yang dihasilkan harus dikelola dengan baik agar tidak menimbulkan dampak negatif bagi pasien, pengunjung, pegawai, dan masyarakat sekitar. Tujuan penelitian adalah untuk Analisis Penerapan Akuntansi Lingkungan Dalam Pengelolaan Limbah Dan Tanggung Jawab Sosialpada Rumah Sakit Stroke Nasional Bukittinggi. Penelitian ini merupakan penelitian kualitatif. Teknik pengumpulan data adalah wawancara dan dokumentasi dan data yang digunakan adalah data primer dan sekunder. Hasil penelitian ditemukan Rumah Sakit Nasional Stroke Bukittinggi sudah melakukan proses Pengidentifikasian, Pengakuan, Pengukuran, Pencatatan, Penyajian, dan juga Pengungkapan seperti halnya yang sudah di jelaskan pada Standar Akuntansi Pemerintahan per 13 Juni 2010. SAP No. 1 tersebut menjelaskan tentang penyajian laporan keuangan. Dimana Rumah Sakit Nasional Stroke Bukittinggi. Rumah Sakit Nasional Stroke Bukittinggi sudah melakukan pengelolahan limbah mereka dengan baik. Rumah Sakit Nasional Stroke Bukittinggi yang sudah mengeluarkan biaya-biaya lingkungannya
\end{abstract}




\section{Pendahuluan}

Akhir - akhir ini banyak isu lingkungan yang muncul. Persoalan mengenai lingkungan saat ini semakin mendapatkan perhatian dan dianggap sebagai isu yang penting. Bagaimana tidak banyak kasus kasus kerusakan lingkungan yang terjadi di Indonesia, secara tidak sadar dampak atas kerusakan lingkungan mulai kita rasakan saat ini. Mulai banyak seruan - seruan mengenai pentingnya menjaga kelestarian lingkungan, namun hal tersebut seakan tidak berpengaruh justru kerusakan lingkungan makin banyak terjadi. Kerusakan lingkungan yang terjadi berkaitan dengan dampak operasi perusahaan, perlu adanya alat kontrol dan sistem tata kelola mengenai dampak kerusakan lingkungan yang diakibatkan operasi perusahaan, akuntansi lingkungan dianggap sebagai solusi terbaik dalam mengatasi masalah kerusakan lingkungan, akutansi lingkungan merupakan bentuk pertanggung jawaban perusahaan atas pengelolaan dampak kerusakan lingkungan yang diakibatkan oleh operasi perusahaan.

Rumah sakit sebagai salah satu sarana atau bantuan kesehatan yang memberikan pelayanan kesehatan kepada masyarakat memiliki peranan yang sangat strategis dalam mempercepat peningkatan kesehatan masyarakat. Oleh karena itu, rumah sakit dituntut untuk memberikan pelayanan yang bermutu sesuai dengan standar yang ditetapkan dan dapat menjangkau seluruh lapisan masyarakat. Pelayanan kesehatan yang bermutu adalah pelayanan kesehatan yang dapat memuaskan setiap pemakai jasa layanan yang sesuai dengan tingkat kepuasan rata-rata penduduk serta penyelenggaraannya sesuai dengan standar dan kode etik profesi yang telah ditetapkan.

Menurut

Permenkes, 1204/Menkes/PerXI/2004 yang mengatur tentang persyaratan Kesehatan Lingkungan
Rumah Sakit, rumah sakit sebagai sarana pelayanan kesehatan, tempat berkumpulnya orang sakit maupun orang sehat ataupun dapat menjadi tempat penularan penyakit serta memngkinkan terjadinya pencemaran lingkungan dan gangguan kesehatan. Untuk menghindari resiko dang gangguan kesehatan maka perlu penyelenggaraan kesehatan lingkungan rumah sakit.Terkait tanggung jawab yang dibebankan kepada rumah sakit atas timbulnya permasalahan lingkungan seperti kegiatan pengelolahan limbah akibat kegiatan operasionalnya, tentunya rumah sakit harus mengeluarkan biaya lingkungan terkait pengelolahan limbah.

Dalam pengorganisasian suatu sistem, seperti rumah sakit tidak akan terlepas dari keinginan melalukan kontrol terhadap apa yang dilakukan rumah sakit secara sistem sehingga tidak menimbulkan dampak negatif misalnya polusi udara, limbah produksi, kesenjangan sosial, dan lain sebagainya dan dampak semacam inilah yang dinamakan Externality. Oleh karena faktor tersebut kemudian memberikan sebuah pikiran untuk mengembangkan ilmu akutansi yang bertujuan untuk mengontrol tanggung jawab perusahaan. Adanya tuntutan yang sudah pernah terjadi tentang masalah Corporate Social Responsibility atau yang dikenal dengan CSR, maka akuntansi bukan hanya merangkum informasi data keuangan antara pihak perusahaan dengan pihak ketiga namun juga mengatasi hubungan dengan lingkungan. Ilmu akuntasi yang mengatur proses pengukuran, penyajian, pengungkapan, dan pelaporan externality tersebut disebut dengan akuntasi lingkungan.

Atas dasar semua itu Rumah Sakit Stroke Nasional Bukittinggi dipilih untuk menjadi objek penelitian ini. Rumah Sakit Stroke Nasional Bukittinggi merupakan salah satu Rumah Sakit Pemerintah yang telah menjadi Badan Layanan Umum ( BLU 
) sehingga dalam menjalankan tugas pokok dan fungsinya Rumah Sakit dapat menerapkan pola keuangan yang fleksibel sebagai Badan Layanan Umum. Pola pengelolaan keuangan pada BLU merupakan pola pengelolaan keuangan yang memberikan fleksibilitas berupa keleluasaan untuk menerapkan praktik-praktik bisnis yang sehat untuk meningkatkan pelayanan kepada masyarakat dalam rangka memajukan kesejahteraan dan mencerdaskan kehidupan bangsa.

Dalam proses pelayanan jasa Rumah Sakit Stroke Nasional Bukittinggi berpotensi menghasilkan limbah. Limbah yang dihasilkan oleh Rumah Sakit Stroke Nasional Bukittinggi adalah limbah medis berupa limbah padat dan limbah cair. Dalam Pengelolahan limbah tersebut Rumah Sakit Stroke Nasional Bukittinggi memiliki Incenerator yang digunakan untuk pembakaran limbah. Sedangkan untuk pengelolahan limbah cair Rumah Sakit Stroke Nasional Bukittinggi memiliki IPAL ( Instalasi Pengelolahan Air Limbah ). Limbah yang dihasilkan harus dikelola dengan baik agar tidak menimbulkan dampak negatif bagi pasien, pengunjung, pegawai, dan masyarakat sekitar.

Oleh sebab itu penulis tertarik untuk melaukan penelitian tentang akuntasi lingkungan yang berjudul: " ANALISIS

PENERAPAN

LINGKUNGAN

AKUNTANSI

PENGELOLAAN

DALAM

TANGGUNG JAWAB SOSIALPADA RUMAH SAKIT STROKE NASIONAL BUKITTINGGI"

\section{Perumusan Masalah}

Sesuai dengan uraian diatas, permasalah yang timbul dapat dirumuskan sebagai berikut:

1. Bagaimana penerapan Akuntansi lingkungan di Rumah Sakit Stroke
Nasional Bukitinggi diliat dari dampak internal dan dampak external?

2. Bagaimana proses pengolahan limbah dan tanggung jawab sosial yang sudah dilakukan oleh pihak Rumah Sakit Stroke Nasional Bukittinggi?

\section{Tujuan Penelitian}

Berdasarkan latar belakang dan rumusan masalah yang telah disebutkan diatas, maka tujuan dalam penelitian ini dapat dijabarkan sebagai berikut :

1. Untuk mengetahui penerapan akuntansi lingkungan yang dilakukan oleh Rumah Sakit Stroke Nasional Bukitinggi diliat dari dampak internal dan dampak external

2. Untuk mengetahui proses pengelolaan limbah dan tanggung jawab sosial pada Rumah Sakit Stroke Nasional Bukittinggi?

\section{Pengertian Akuntansi Lingkungan}

Menurut Suartana (2010), akuntasi lingkungan adalah suatu istilah yang berupaya untuk mengelompokkan pembiayaan yang dilakukan perusahaan atau pemerintah dalam melalukan konservasi lingkungan kedalam pos lingkungan dan praktik bisnis perusahaan.

Menurut (Ikhsan, 2008) akuntasi lingkungan adalah identifikasi, pengukuran dan alokasi biaya - biaya ke dalam pengambilan keputusan usaha serta mengkomunikasikan hasilnya kepada para stockhoulders perusahaan. Akuntasi lingkungan (Environmental Accounting) adalah istilah yang berkaitan dengan dimasukannya biaya lingkungan (Environmental costs) kedalam praktek akuntasi perusahaan. Biaya lingkungan adalah dampak (impact) baik moneter maupun non - nometer yang harus dipikul sebagai akibat dari kegiatan yang mempengaruhi kualitas lingkungan. 


\section{Tujuan Akuntansi Lingkungan}

Menurut Hermiyetti dan Dondokambey (2012), tujuan akuntansi lingkungan adalah :

a. Sebagai alat manajemen lingkungan Untuk menilai keefektifan kegiatan konservasi berdasarkan ringkasan dan klarifikasi biaya konservasi lingkungan. Data akuntansi lingkungan juga digunakan menentukan biaya fasilitas pengelolaan lingkungan, menilai tingkat keluaran dan mencapai tiap tahun agar menjamin perbaikan kinerja lingkungan yang berlangsung secara terus menerus.

b. Sebagai alat komunikasi dengan masyarakat

Akuntansi lingkungan digunakan untuk menyampaikan dampak disampingkan kepada publik. Tanggapan dan pandangan terhadap akuntansi lingkungan dari para pihak pelanggan dan masyarakat digunakan sebagai umpan balik perusahaan dalam pengelolaan lingkungan

\section{Pentingnya Akuntansi Lingkungan}

Biaya lingkungan merupakan salah satu beberapa tipe biaya yang dikorbankan seperti halnya perusahaan memberikan barang dan jasa kepada konsumen. Kinerja lingkungan merupakan salah satu dari beberapa ukuran penting tentang keberhasilan perusahaan. Beberapa alasan manajemen perlu memperhatikan biaya lingkungan dan kinerja lingkungan menurut Sudarno (2008) antara lain:

1. Beberapa biaya lingkungan dapat dikurangi dan dieliminasi secara signifikan sebagai hasil dari keputusan bisnis, mulai dari operasi perubahan pergudangan, ke investasi dalam teknologi memprosesan yang lebih hijau, meredasain proses atau produk.

2. Biaya lingkungan (misalnya biaya penghematan biaya lingkungan secara potensial) dapat dikaburkan dalam akun biaya overhead atau bahkan diabaiakan.

3. Beberapa perusahaan telah menemukan bahwa biaya lingkungan dapat di offet dengan perolehan pendapat melalui penjualan limbah, produk sampingan atau cadangan polusi yang dipindahkan atau lisensi teknologi untuk penjumlahan.

4. Manajeman baiaya lingkungan yang lebih baik dapat dihasilkan dengan mengembangkan kinerja lingkungan dan memperoleh manfaat yang signifikan terhadap kesehatan manusia seperti halnya dalam keberhasilan bisnis.

5. Dengan biaya limgkungan dan kinerja lingkungan, pemprosesan dan produk dapat memperbaiki penempatan biaya produk dan penempatan harga yang lebih tepat dan dapat membantu perusahaan dalam mendesain pemrosesan, produk dan jasa yang lebih ramahlingkungan dimasa depan.

6. Keunggulan kompetitif terhadap pelanggan dapat dihasilkan dari pemrosesan, produk jasa yang dapat dijelaskan dengan lingkungan yang lebih baik.

7. Akuntansi biaya dan kinerja lingkungan dapat mendukung pengembangan perusahaan dan operasi sistem manajemen lingkungan secara menyeluruh.

\section{Fungsi dan Peran Akuntansi Lingkungan}

Masing-masing fungsi tersebut dijelaskan sebagai berikut:

1. Fungsi Internal

Fungsi internal merupakan fungsi yang berkaitan dengan pihak internal perusahaan sendiri. Pihak internal adalah pihak yang menyelenggarakan usaha, seperti rumah tangga konsumen 
dan rumah tangga produksi maupun jasa lainnya. Adapun yang menjadi actor dan factor dominan pada fungsi internal ini adalah pimpinan perusahaan. Sebab pimpinan perusahaan merupakan orang yang bertanggung jawab dalam setiap pengambilan keputusan maupun penentuan setiap kebijakan internal perusahaan. Sebagaimana lainnya dengan system informasi lingkungan perusahaan, fungsi internal memungkinkan untuk mengatur biaya konservasi lingkungan dan menganalisis biaya dari kegiatankegiatan konservasi lingkungan yang efektif dan efisien serta sesuai dengan pengambilan keputusan. Dalam fungsi internal ini diharapkan akuntansi lingkungan berfungsi sebagai alat manajemen bisnis yang dapat digunakan oleh manajar ketika berhubungan dengan unit-unit bisnis.

2. FungsiEksternal

Fungsi eksternal merupakan fungsi yang berkaitan dengan aspek pelaporan keuangan. Pada fungsi ini faktor penting yang perlu diperhatikan perusahaan adalah pengungkapan hasil dari kegiatan konservasi lingkungan dalam bentuk data akuntansi. Informasi yang diungkapkan merupakan hasil yang diukur secara kuantitatif dari kegiatan konservasi lingkungan. Termasuk didalamnya adalah informasi tentang sumber-sumber ekonomi suatuperusahaan.

\section{Sandar Akuntansi Pemerintahan}

(SAP) ditetapkan dengan Peraturan Pemerintah No. 71 Tahun 2010 sebagai pengganti Peraturan Pemerintah No. 24 Tahun 2005. SAP dinyatakan dalam bentuk Pernyataan Standar Akuntansi Pemerintahan (PSAP), dilengkapi dengan Pengantar
Standar Akuntansi Pemerintahan dan disusun mengacu kepada Kerangka Konseptual Akuntansi Pemerintahan.

Pencatatan untuk mengelola segala macam yang berkaitan dengan limbah sebuah perusahaan didahului dengan perencanaan yang akan dikelompokkan dalam pos-pos tertentu sehingga dapat diketahui kebutuhan riil setiap tahunnya.Pengelompokkan dalam tahap analisis lingkungan ruang lingkupnya berbeda. Ada PSAK yang menaungi perusahaan yang terdaftar di BEI. SAK yang menaungi perusahaan kecil dan menengah yang tidak terdaftar di BEI. PSAK Syariah yang menaungi transaksi berbasis syariah dan PSAP yang menaungi lembaga pemerintahan. Berhubung penelitian ini obyeknya adalah rumah sakit pemerintahan maka dari itu, penulis mengacu pada PSAP. Bagaimana yang sudah ditentukan dalam Pernyataan Standar Akuntansi Pemerintahan (PSAP) No. 1 tahun 2010 antara lain sebagai berikut :

1. Pengidentifikasian. Berdasarkan klasifikasi atas biaya lingkungan oleh Hansen \& Mowen, maka biaya lingkungan dibagi ke dalam empat kategori yaitu

a. Biaya pencegahan lingkungan.

b. Biaya deteksi lingkungan

1) Uji Baku Mutu Limbah Cair.

2) Uji Baku Mutu Udara.

c. Biaya kegagalan internal lingkungan.

d. Mengolah limbah padat dengan Incinerator

1) Mengolah limbah cair dengan

2) Instalasi Pengolahan Limbah Cair.

e. Biaya kegagalan eksternal lingkungan.

Seperti pembersihan danau dan tanah yang tercemar, hilangnya lapangan pekerjaan karena pencemaran, dan lain-lain. 
2. Pengakuan.

Menurut Kerangka Dasar Penyusunan dan Penyajian Laporan Keuangan, pengakuan merupakan suatu proses pembentukan suatu pos yang emenuhi definisi unsur serta kriteria pengakuan yang dikemukakan dalam neraca atau laporan laba rugi.Pos yang memenuhi definisi suatu unsur harus diakui kalau :

a. Ada kemungkinan bahwa manfaat ekonomi yang berkaitan dengan pos tersebut akan mengalir dari atau ke dalam perusahaan.

b. Pos tersebut mempunyai nilai atau biaya yang dapat diukur dengan andal.

3. Pengukuran.

Menurut Kerangka Dasar Penyusunan dan Penyajian Laporan Keuangan, pengukuran adalah proses penetapan jumlah uang untuk mengakui dan memasukkan setiap unsur laporan keuangan dalam neraca dan laporan laba rugi. Proses ini menyangkut dasar pengukuran tertentu. Berdasarkan hasil pengamatan, pengukuran biaya lingkungan oleh rumah sakit menggunakan nilai historis.

4. Pencatatan

Proses pencatatan adalah proses dari adanya transaksi atau pun dari kegiatan yang sudah di lakukan oleh perusahaan maupun instansi pemerintahan. Dari adanya transaksi ataupun kegiatan tersebut nantinya akan di catat dan akan di gunakan sebagai alat untuk pelaporan dari kegiatan mereka.

5. Penyajian

Menurut Suwardjono (2005) penyajian menetapkan tentang cara-cara melaporkan elemen atau pos dalam seperangkat laporan keuangan agar elemen atau pos tersebut cukup informatif, standar akuntansi biasanya memuat ketentuan tentang apakah suatu informasi objek harus disajikan secara terpisah dari laporan utama, apakah suatu informasi harus disajikan digabung dengan akun laporan keuangan yang lain, apakah suatu pos perlu dirinci, atau apakah suatu informasi cukup disajikan dalam bentuk catatan kaki.

6. Pengungkapan.

Pengungkapan dalam akuntansi lingkungan merupakan jenis pengungkapan

sukarela.Pengungkapan akuntansi lingkungan merupakan pengungkapan informasi data akuntansi lingkungan dari sudut pandang fungsi internal akuntansi lingkungan itu sendiri, yaitu berupa laporan akuntansi lingkungan.Laporan tersebut harus didasarkan pada situasi actual pada suatu perusahaan atau organisasi lainnya. Data aktual diungkapkan ditentukan oleh perusahaan sendiri atau organisasi lainnya. Oleh karena itu diperlukan ketika pengungkapan data eksternal akuntansi.lingkungan untuk mengklarifikasi prasarat dari pengungkapan data, supaya stakeholders memperoleh pemahaman konsistensi dari data akuntansi lingkungan.

\section{Metode Penelitian}

Penelitian ini merupakan penelitian kualitatif . Populasi dalam penelitian ini adalah Rumah Sakit Stroke Nasional Bukittinggi. Informan penelitian terdiri dari petugas yang terkait dengan pengelolaan limbah rumah sakit dan bagian keuangan. 
Data yang digunakan adalah data primer dan data sekunder. Metode analisis yang digunakan adalah uji t-test

\section{Analisis dan Pembahasan}

\section{Penerapan Akuntansi Lingkungan di Rumah Sakit Stroke Nasional Bukitinggi Diliat Dari Dampak Internal Dan Dampak External}

\section{Faktor Internal}

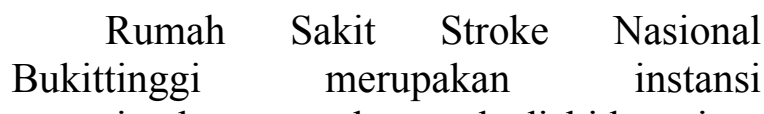
pemerintahan yang bergerak di bidang jasa kesehatan. Dalam melaporkan biayanya untuk pengelolahan lingkungan khususnya biaya pengelolahan limbah di akui sebagai belanja langsung, belanja tidak langsung dan belanja barang dan jasa.

Hal ini didukung oleh penelitian yang dilakukan oleh penelitian Aminah Noviani (2014), penelitian ini mengemukakan bahwa perlakuan alokasi biaya lingkungan yang dilakukan oleh RS Mardi Waluyo dilakukan oleh bagian keuangan RS secara langsung dengan Unit Sanitasi Lingkungan yang diakui sebagai salah satu aset tetap (aktiva tetap) rumah sakit dengan konsekuensi logis biaya yang dikeluarkan oleh unit tersebut selama operasional diakui sebagai biaya operasional rumah sakit yang berpengaruh pada laporan keuangan RS Mardi Waluyo Metro. Penelitian Fitri Nilasari ( 2014 ), berdasarkan hasil penelitian dapat diketahui bahwa perusahaan telah melakukan tahapan perlakuan akuntansi biaya pengelolaan limbah, didasarkan adanya pengklasifikasian biaya pengelolaan limbah. Biaya-biaya tersebut diakui dalam perkiraan pabrik yang merupakan komponen pennyusunan harga pokok penjualan. Pabrik juga telah mengungkapkan kebijakan akuntansi biaya lingkungan dalam Catatan Atas Laporan Keuangan. Penelitian Shela Ika Mardikawati (2014), Dalam penerapan Akuntansi manajemen Lingkungan PT. II, perhitungan laporam biaya lingkungan dilakukan dengan menghitung dan mempertimbangkan seluruh aktivitas produksi yang telah dilakukan oleh perusahaan. Dalam pelaporan biaya lingkungan perusahaan menggabungkan seluruh pengeluaran aktivitasnya.

Penelitian Desi dan Henny (2011), Sistem manajemen lingkungan yang ada pada rumah sakit sesuai dengan kebijakan manajemen atas sistem pengelolaan limbah yang dilakukan RSUP Persahabatan dan sistem manajemen lingkungan tersebut sudah cukup baik melaksanakan kebijakan yang dikeluarkan. Penelitian Titik Kusumawati ( 2014 ), Biaya - biaya yang timbul terkait pengelolaan limbah RSUD dr. R. Koesma Tuban terdiri atas biaya pemeliharaan, biaya bahan bakar, biaya retribusi, dan biaya listrik. Rumah Sakit juga memperoleh pendapatan jasa dari pengolahan limbah padat medis menggunakan incenerator.

Setelah melakukan penelusuran berdasarkan bukti-bukti yang ada terkait dengan biaya-biaya lingkungan yang terdapat di Rumah Sakit Stroke Nasional Bukittinggi, rumah sakit sudah mengeluarkan biaya-biaya yang berkaitan dengan kegiatan lingkungannya tetapi biayabiaya tersebut belum di identifikasi secara khusus oleh pihak rumah sakit, di karenakan identifikasi yang di lakukan oleh pihak Rumah Sakit Stroke Nasional Bukittinggi dalam melakukan tahapan-tahapan perlakuan biaya lingkungan di perlakukan sebagai komponen operasional.

Undang-undang No. 32 Tahun 2009 tentang perlindungan dan pengelolahan lingkungan hidup salah satu poinnya menjelaskan bahwa : Setiap penanggung jawab usaha atau kegiatan wajib melakukan pengelolahan bahan berbahaya dan beracun.

Sedangkan Undang-Undang No. 25 Tahun 2007 tentang penanaman modal salah satu poinnya juga menjelaskan bahwa : 
Melaksanakan tanggung jawab sosial perusahaan, menjaga kelestarian lingkungan, menciptakan keselamatan, kesehatan, kenyamanan dan kesejahteraan pekerja.

Indonesia sebagai negara hukum yang tentunya mewajibkan bagi warganya untuk mematuhi perundang-undangan yang ada. Dan tentunya akan memberikan sanksi kepada siapapun yang melanggarnya termasuk instansi dari pemerintaha.

Undang-undang tersebut menerangkan tentang pentingnya melindungi lingkungan di sekitar kita khususnya bagi instansi yang melakukan kegiatan yang berpotensi menghasilkan limbah dengan cara memberikan aturan kepada mereka tentang pengelolahan limbah yang mereka hasilkan. Dari kedua Undang-Undang tersebut, penulis mengidentifikasi adanya biaya-biaya yang di keluarkan rumah sakit guna untuk mematuhi adanya Undang-Undang No. 32 Tahun 2009 dan Undang-Undang No. 25 Tahun 2007 pada tabel berikut ini:

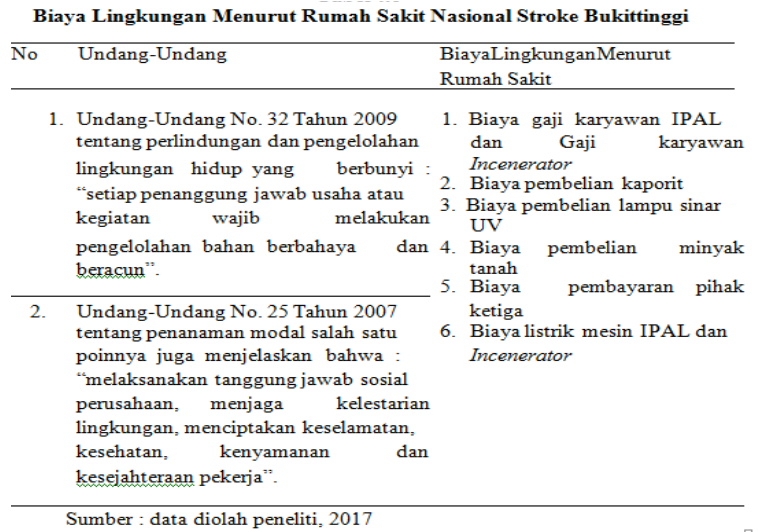

Dari hasil identifikasi pada tabel 4.3 dapat di ketahui bahwa Rumah Nasinal Stroke Bukittinggi sudah melakukan klasifikasi biaya ingkungan yang bertujuan untuk mematuhi peraturan dari negara yang berupa Undang-Undang yang ada. Kedua Undang- Undang tersebut mewajibkan bagi instansi yang menghasilkan bahan berbahaya dan beracun untuk mengelolanya dan menjalankan tanggung jawab sosial, menjaga kelestarian lingkungan, menciptakan keselamatan, kesehatan, kenyamanan dan kesejahteraan pekerja. Rumah Nasional Stroke Bukittinggi tampaknya sudah menjalankan itu semua. Dengan cara mengelola limbah berbahaya dan beracun yang mereka hasilkan maka kingkungan di sekitar mereka pun dapat terjaga dengan baik. Tanggung jawab sosial pun sudah mereka kerjakan dan dengan adanya pengelolahan limbah tersebut maka dapat menciptakan keselamatan, kesehatan, kenyamanan dan kesejahteraan para pekerjanya.

\section{Mengakui Biaya Lingkungan Rumah Sakit Nasional Stroke Bukittinggi}

Pada PSAP No. 1 Tahun 2010 menjelaskan adanya Pengakuan. Menurut Kerangka Dasar Penyusunan dan Penyajian Laporan Keuangan, pengakuan merupakan suatu proses pembentukan suatu pos yang memenuhi definisi unsur serta kriteria pengakuan yang dikemukakan dalam neraca atau laporan realisasi anggaran.

Pos yang memenuhi definisi suatu unsur harus diakui kalau :

1) Ada kemungkinan bahwa manfaat ekonomi yang berkaitan dengan pos tersebut akan mengalir dari atau ke dalam perusahaan ataupun instansi.

2) Pos tersebut mempunyai nilai atau biaya yang dapat diukur dengan andal.

Proses pengelolahan limbah yang telah di lakukan rumah sakit tentunya masuk dalam pos unsur yang harus di lakukan pengakuan. Adanya manfaat ekonomi yang yang berkaitan dengan pengelolahan limbah dari Rumah Sakit Nasional Stroke Bukittinggi yang tentunya yang mengalir dari perusahaan yang di tujukan untuk 
pengelolahan limbah demi menjaga lingkungan di sekitarnya.

Pos biaya pengelolahan limbah Rumah Sakit Nasional Stroke Bukittinggi juga mempunyai nilai dan biaya yang dapat di ukur dengan andal. Rumah Sakit Nasional Stroke Bukittinggi melakukan pengakuannya menggunakan Akrul basis dimana hal ini mengacu pada peraturan Pemendagri No. 64 Tahun 2013 tentang penerapan akuntansi berbasis full akrual di pemerintahan pada tahun 2015. Sehingga dapat di simpulkan bahwa pihak Rumah Sakit Nasional Stroke Bukittinggi sudah melakukan pengakuan seperti apa yang ada di PSAP No. 1 tahun 2010 dan mengikuti peraturan yang mendukung adanya PSAP No.1 Tahun 2010 yaitu peraturan Pemendagri No. 64 Tahun 2013 tentang penerapan akuntansi berbasis full akrual di pemerintahan pada tahun 2015 .

\section{Mengukur Biaya Lingkungan}

Pada PSAP No. 1 Tahun 2010 menjelaskan adanya pengukuran. Menurut Kerangka Dasar Penyusunan dan Penyajian Laporan Keuangan, pengukuran adalah proses penetapan jumlah uang untuk mengakui dan memasukkan setiap unsur laporan keuangan dalam neraca dan laporan realisasi anggaran. Proses ini menyangkut dasar pengukuran tertentu. Berdasarkan hasil pengamatan, pengukuran biaya lingkungan oleh rumah sakit menggunakan nilai historis. Pengukuran biaya lingkungan menggunakan satuan mata uang Rupiah.

Rumah Sakit Nasional Stroke Bukittinggi dalam mengukur nilai dan jumlah biaya yang di keluarkan untuk pembiayaan lingkungan (dalam hal biaya pengelolahan limbah) menggunakan satuan moneter sebesar kos yang akan di keluarkan.

\section{Mencatat Biaya Lingkungan}

PSAP No. 1 Tahun 2010 menjelaskan adanya pencatatan. Proses pencatatan adalah proses dari adanya transaksi atau pun dari kegiatan yang sudah di lakukan oleh perusahaan maupun instansi pemerintahan. Dari adanya transaksi ataupun kegiatan tersebut nantinya akan di catat dan akan di gunakan sebagai alat untuk pelaporan dari kegiatan mereka. Kegiatan pengelolahan lingkungan menunjukkan adanya transaksi dan kegiatan yang telah di lakukan oleh pihak rumah sakit. Dimana transaksi atau kegiatan tersebut harus di lakukan adanya pencatatan sebagai laporan dari kegiatan mereka nantinya pada akhir tahun. Adanya kegiatan pengelolahan lingkungan yang menunjukkan transaksi dan kegiatan maka akan menimbulkan pencatatan.

Pencatatan tersebut menunjukkan bahwa rumah sakit sudah melakukan pencatatan atas terjadinya pengelolahan limbah mereka sehingga dapat di katakan bahwa Rumah Sakit Nasional Stroke Bukittinggi sudah melakukan pencatatan atas transaksi atau kegiatan mereka tentang kegiatan pengelolahan limbahnya. Seperti apa yang sudah ada pada PSAP No. 1 Tahun 2010 tentang pencatatan untuk Penyajian Laporan Keuangan

\section{Menyajikan Biaya Lingkungan}

Standar Akuntansi Pemerintahan per 13 Juni 2010, SAP No. 1 tentang penyajian laporan keuangan mengungkapkan dalam paragraf 14, mengenai komponenkomponen yang terdapat dalam suatu laporan keuangan menyatakan bahwa : Komponen-komponen yang terdapat dalam suatu set laporan keuangan pokok adalah laporan realisasi anggaran, neraca, laporan arus kas dan catatan atas laporan keuangan. Paragraf 106 juga menyebutkan bahwa :

1. Suatu entitas pelaporan mengungkapkan hal-hal berikut ini apabila belum di informasikan dalam bagian manapun dari laporan keuangan, yaitu : 
a. Domisili dan bentuk hukum suatu entitas serta jurisdiksi dimana entitas tersebut beroperasi.

b. Penjelasan mengenai sifat operasi entitas dan kegiatan pokoknya.

c.Ketentuan perundang-undangan yang menjadi landasan kegiatan operasionalnya.

Berdasarkan penjelasan di atas, bisa di katakan bahwa Standar Akuntansi Pemerintahan (SAP) mengharuskan bagi instansi pemerintahan yang berpotensi menghasilkan limbah untuk mengungkapkan aktivitas lingkungannya yang terkait sangat erat dengan limbah operasional sebagai suatu bentuk laporan tambahan untuk melengkapi laporan keuangan yang utama yang sudah di wajibkan. Penyajian biaya lingkungan ini di dalam laporan keuangan dapat di lakukan dengan nama rekening yang berbeda-beda sebab sejauh ini tidak ada sebuah aturan yang baku untuk sebuah nama rekening untuk memuat alokasi pembiayaan lingkungan yang di keluarkan oleh instansi pemerintahan.

Selama ini Rumah Sakit Nasional Stroke Bukittinggi menyajikan biaya lingkungannya (dalam hal pengelolahan biaya limbah) dalam kelompok biaya operasional rumah sakit di dalam sub sub unit yang sejenis dalam laporan realisasi anggaran. Rumah Sakit Nasional Stroke Bukittinggi belum melaporkan dan menyajikan biaya lingkungan dalam laporan secara khusus akan tetapi Rumah Sakit Nasional Stroke Bukittinggi sudah melakukan pelaporan atas kegiatan pengelolahan limbahnya pada laporan keuangan mereka. Pada laporan realisasi anggaran mereka, pada neraca dan juga pada laporan arus kas mereka.

\section{Mengungkapkan Biaya Lingkungan}

Pengungkapan dalam biaya lingkungan merupakan jenis pengungkapan sukarela. Pengungkapan akuntansi lingkungan merupakan pengungkapan informasi data akuntansi lingkungan dari sudut pandang fungsi internal akuntansi lingkungan itu sendiri, yaitu berupa laporan akuntansi lingkungan. Laporan tersebut harus didasarkan pada situasi aktual pada suatu perusahaan atau organisasi lainnya. Data aktual diungkapkan ditentukan oleh perusahaan sendiri atau organisasi lainnya.

Sehubungan dengan biaya pengelolahan limbah yang masuk ke dalam belanja pegawai langsung dan belanja pegawai tidak langsung, pihak rumah sakit sudah mengungkapkan dalam catatan atas laporan keuangan tentang kebijakan akuntansi yang di ambil dan di terapkan oleh perusahaan yang berkaitan dengan masalah prosedur pembebanan biaya pengelolahan limbah ke dalam belanja pegawai langsung dan belanja pegawai tidak langsung.

Standar Akuntansi Pemerintahan per 13 Juni 2010, SAP No. 1 tentang penyajian laporan keuangan mengungkapkan pada paragraf 19 menjelaskan tentang informasi tambahan dinyatakan bahwa : Entitas pelaporan menyajikan informasi tambahan untuk membantu para pengguna dalam memperkirakan kinerja keuanganentitas dan pengelolahan aset, seperti halnya dalam pembuatan dan evaluasi keputusan mengenai alokasi sumberdaya ekonomi. Informasi tambahan ini termasuk rincian mengenai output entitas dan outcomes dalam bentuk indikator kinerja keuangan, laporan kinerja keuangan, tinjauan program dan laporan lain mengenai pencapaian kinerja keuangan entitas selama periode pelaporan

Pada paragraf tersebut menyatakan bahwa entitas pelaporan menyajikan informasi tambahan untuk membantu para pengguna. Akuntansi lingkungan termasuk salah satu di antara pelaporan tambahan itu, namun pada SAP No. 1 tentang penyajian laporan keuangan tentang akuntansi lingkungan ini masih bersifat sukarela. Sehingga jika ada pihak yang tidak 
mencantumkan penyajian secara khusus tentang pelaporan akuntansi lingkungan pun tidak melanggar peraturan yang ada.

Begitupun pihak Rumah Sakit Nasional Stroke Bukittinggi belum mengungkapkan secara khusus tentang penyajian akuntansi lingkungan mereka namun sudah menyajikannya pada lapora keuangan umum. Masuk pada biaya-biaya yang serumpun seperti belanja pegawai dan belanja barang dan jasa.

\subsubsection{Faktor Eksternal}

Tanggung jawab sosial yang di maksud pada penelitian ini adalah bagaimana mekanisme bagi suatu organisasi untuk mengintegrasikan perhatian terhadap lingkungan dan sosial ke dalam operasinya, terlebih jika organisasi tersebut berpotensi menghasilkan limbah. Rumah Sakit Stroke Nasional Bukittinggi termasuk salah satunya. Dimana rumah sakit adalah suatu organisasi yang kegiatan operasionalnya berpotensi menghasilkan limbah terlebih limbah tersebut adalah limbah yang berbahaya. Tentunya jika limbah tersebut di buang begitu saja tanpa di kelola maka akan dapat membahayakan lingkungan di sekitar terlebih makhluk hidupnya.

Mengacu pada Undang-Undang No. 32 Tahun 2009 tentang perlindungan dan pengelolahan lingkungan hidup, dan Undang-Undang No. 25 Tahun 2007 tentang penanaman modal. Dimana pada dua Undang-Undang tersebut mengatur akan kewajiban orang yang melakukan usaha hendaknya melakukan pengelolahan limbah hasil usahanya. Jika tidak mengelola limbah hasil usahanya, maka pemilik usaha akan di pidanakan atau mendapatkan denda.

\section{Proses Pengelolaan Limbah Dan Tanggung Jawab Sosial pada Rumah Sakit Stroke Nasional Bukittinggi}

\section{Proses Pengelolaan Limbah}

Pengelolaan limbah Rumah Sakit harus dilakukan dengan benar dan efektif dan memenuhi persyaratan sanitasi. Sebagai sesuatu yang tidak digunakan lagi, tidak disenangi, dan yang harus dibuang maka limbah tentu harus dikelola dengan baik. Syarat yang harus dipenuhi Rumah Sakit Stroke Nasional Bukittinggi dalam pengelolaan limbah ialah tidak mencemari udara, air, atau tanah, tidak menimbulkan bau (segi estetis) tidak menimbulkan kebakaran, dan sebagainya agar masyarakt disekiling tidak tercemar dengan limbah yang diproduksi rumah sakit. Berdasarkan Undang-Undang Republik Indonesia Nomor 18 tahun 2008 pengelolaan limbah merupakan kegiatan yang sistematis, menyeluruh, dan berkesinambungan yang meliputi pengurangan dan penanganan limbah.

$\begin{array}{cr}\text { Menurut } & \text { Kepmenkes } \\ \text { 1204/Menkes/SK/X/2004 } & \text { Tentang }\end{array}$
Persyaratan Kesehatan Lingkungan Rumah Sakit didalam pelaksanaan pengelolaan limbah setiap rumah sakit harus melakukan reduksi limbah dimulai dari sumber, harus mengelola dan mengawasi penggunaan bahan kimia yang berbahaya dan beracun, harus melakukan pengelolaan stok bahan kimia dan farmasi. Setiap peralatan yang digunakan dalam pengelolaan limbah medis mulai dari pengumpulan, pengangkutan, dan pemusnahan harus melalui sertifikasi dari pihak yang berwenang.

Hal ini dapat dilaksanakan oleh Rumah Sakit Stroke Nasional Bukittinggi dengan melakukan :

a. Menyeleksi bahan-bahan yang kurang menghasilkan limbah sebelum membelinya. 
b. Menggunakan sedikit mungkin bahanbahan kimia.

c. Mengutamakan metode pembersihan secara fisik daripada secara kimiawi.

d. Mencegah bahan-bahan yang dapat menjadi limbah seperti dalam kegiatan perawatan dan kebersihan.

e. Memonitor alur penggunaan bahan kimia dari bahan baku sampai menjadi limbah bahan berbahaya dan beracun.

f. Memesan bahan-bahan sesuai kebutuhan.

g. Menggunakan bahan-bahan yang diproduksi lebih awal untuk menghindari kadaluarsa.

h. Menghabiskan bahan dari setiap kemasan.

i. Mengecek tanggal kadaluarsa bahanbahan pada saat diantar oleh distributor.

Pengelolaan limbah layanan

kesehatan merupakan bagian yang tidak terpisahkan dari hygiene rumah sakit dan pengendalian infeksi. Limbah layanan kesehatan sebagai reservoir mikroorganisme pathogen, yang dapat menyebabkan kontaminasi dan infeksi. Jika limbah tidak dikelola dengan tepat, mikroorganisme dapat berpinadah melalui kontak langsung, diudara atau melalaui vector (lalat, tikus dan lain-lain).

Pada proses pengelolaan limbah diperlukan juga perangkat penunjang merupakan sarana dan prasarana yang digunakan untuk kegiatan tersebut. Perangkat tersebut harus mempertimbangkan aspek ketersediaan anggaran, jumlah kunjungan dan lama rawat inap pasien, serta berbagai pertimbangan teknis yang lain.

Kesehatan masyarakat dan resiko kesehatan kerja dalam menggunakan sistim pengelolaan limbah layanan kesehatan sebagai berikut:
1. Pembakaran atau pengolahan menggunakan steam/uap (autoclave)

2. Suhu tinggi, incinerator bahan bakar minyak sekala menengah
3. Suhu tinggi incinerator bio-mass sekala kecil

4. Pengontrolan sanitasi lokasi penimbunan tanpa pengolahan tapi paling sedikit sehari-hari limbah tertanggulagi

\section{Tanggung Jawab Sosial pada Rumah Sakit Stroke Nasional Bukittinggi}

Menurut Permenkes, 1204/Menkes/PerXI/2004 yang mengatur tentang persyaratan Kesehatan Lingkungan Rumah Sakit, rumah sakit sebagai sarana pelayanan kesehatan, tempat berkumpulnya orang sakit maupun orang sehat ataupun dapat menjadi tempat penularan penyakit serta memngkinkan terjadinya pencemaran lingkungan dan gangguan kesehatan. Untuk menghindari resiko dang gangguan kesehatan maka perlu penyelenggaraan kesehatan lingkungan rumah sakit.Terkait tanggung jawab yang dibebankan kepada rumah sakit atas timbulnya

permasalahan lingkungan seperti kegiatan pengelolahan limbah akibat kegiatan operasionalnya, tentunya rumah sakit harus mengeluarkan biaya lingkungan terkait pengelolahan limbah.

Tanggung jawab sosial yang di maksud pada penelitian ini adalah bagaimana mekanisme bagi suatu organisasi untuk mengintegrasikan perhatian terhadap lingkungan dan sosial ke dalam operasinya, terlebih jika organisasi tersebut berpotensi menghasilkan limbah. Rumah Sakit Stroke Nasional Bukittinggi termasuk salah satunya. Dimana rumah sakit adalah suatu organisasi yang kegiatan operasionalnya berpotensi menghasilkan limbah terlebih limbah tersebut adalah limbah yang berbahaya. Tentunya jika limbah tersebut di buang begitu saja tanpa di kelola maka akan dapat membahayakan lingkungan di sekitar terlebih makhluk hidupnya.

Berdasarkan keterangan-keterangan dari warga yang tinggal di lingkungan sekitar, dapat di simpulkan bahwa pihak 
Rumah Sakit Stroke Nasional Bukittinggi sudah mengelolah limbahnya dengan baik sehingga yang awalnya limbah tersebut berbahaya di kelola sehingga menjadi limbah yang aman bagi lingkungan di sekitarnya.

\section{KESIMPULAN DAN SARAN}

\section{Kesimpulan}

Berdasarkan pembahasan mengenai penerapan akuntansi biaya lingkungan dan bagaimana penyajiannya dalam laporan keuangan di Rumah Sakit Nasional Stroke Bukittinggi, maka dapat di simpulkan sebagai berikut :

1. Rumah Sakit Nasional Stroke Bukittinggi sudah melakukan proses Pengidentifikasian, Pengakuan, Pengukuran, Pencatatan, Penyajian, dan juga Pengungkapan seperti halnya yang sudah di jelaskan pada Standar Akuntansi Pemerintahan per 13 Juni 2010. SAP No. 1 tersebut menjelaskan tentang penyajian laporan keuangan. Dimana Rumah Sakit Nasional Stroke Bukittinggi mengakui biaya-biaya lingkungan yang terjadi sebagai biaya operasional. Pengakuan tersebut menggunakan metode akrual basis. Hal ini seperti yang sudah ada pada peraturan Pemendagri No. 64 Tahun 2013 tentang penerapan akuntansi berbasis full akrual di pemerintahan pada tahun 2015. Pengukuran yang di lakukan oleh pihak Rumah Sakit Nasional Stroke Bukittinggi menggunakan harga perolehan yang di keluarkan oleh pihak rumah sakit dan berdasarkan realisasi anggaran di tahun sebelumnya atau biasa di sebut Historical Cost. Dengan begitu anggaran yang di keluarkan pada periode ini tidak jauh berbeda dengan realisasi tahun sebelumnya. Rumah Sakit Nasional Stroke Bukittinggi menyajikan biaya lingkungan dengan memasukkan komponen-komponen biaya lingkungan mereka pada laporan keuangan umum. Mencatat biaya-biaya lingkungan secara keseluruhan yakni dalam lingkup satu ruang rekening secara umum bersama rekening lain yang serumpun. Biayabiaya yang serumpun tersebut di sisipkan dalam sub-sub unit rekening biaya tertentu dalam laporan keuangannya. Rumah Sakit Nasional Stroke Bukittinggi sudah mengungkapkan adanya pengelolahan limbah pada Catatan Atas Laporan Keuangan mereka namun belum mengungkapkan secara khusus. Namun hal itu tidak melanggar Standar Akuntansi Pemerintahan yang ada, dikarenakan akuntansi lingkungan hanya bersifat sukarela.

2. Rumah Sakit Nasional Stroke Bukittinggi sudah melakukan pengelolahan limbah mereka dengan baik. Rumah Sakit Nasional Stroke Bukittinggi yang sudah mengeluarkan biaya-biaya lingkungannya. Hal itu sejalan dengan Undang-undang No. 32 Tahun 2009 tentang perlindungan dan pengelolahan lingkungan hidup dan Undang-Undang No. 25 Tahun 2007 tentang penanaman modal. Dengan di keluarkannya biayabiaya tersebut, Rumah Sakit Ibnu Sina sudah turut melakukan perlindungan dan menjaga lingkungan hidup seperti yang ada pada kedua Undang-Undang tersebut. Namun ada satu hal kurang di perhatikan. Lantaran limbah hasil pembakaran yang berupa asap tidak terlalu berbahaya, pihak rumah sakit tidak mengelola ataupun tidak meminimalisir asap tersebut sehingga warga di sekitar mengeluhkannya. Polusi pun dapat terjadi karena asap-asap pembakaran tersebut. 


\section{Saran}

Peneliti menyadari bahwa dari hasil penelitian yang telah disimpulkan diatas masih terdapat banyak kekurangan dan belum sempurna, namun peneliti mencoba memberikan saran untuk perusahaan agar kedepannya jauh lebih baik lagi yaitu sebagai berikut:

1. Di harapkan bagi pihak rumah sakit untuk mengelola limbah gas dari hasil pembakaran limbah padat yang berupa asap, di karenakan hanya berbentuk asap namun beberapa warga yang berada di sekitar rumah sakit ada yang sedikit terganggu dengan adanya hal tersebut. Meskipun asap tersebut tidak dapat menimbulkan penyakit yang berbahaya kepada warga sekitar, namun hal itu bisa menimbulkan polusi udara dan mengurangi kualitas udara yang ada saat Rumah Sakit Nasional Stroke Bukittinggi melakukan pembakaran limbah padatnya. Entah limbah gas tersebut di minimalisir dengan cara pembakarannya dilakukan saat dini hari, sekitar pukul 02.00. Yang mana kebanyakan para warga di sekitar Rumah Sakit Nasional Stroke Bukittinggi pada jam tersebut sudah jarang beraktifitas. Ataupun dengan cara yang lainnya.

2. Sedangkan bagi peneliti selanjutnya yang membahas akuntansi lingkungan, hendaknya menganalisis dari sisi laporan keuangan rumah sakit yang berdasarkan Standar Akuntansi Keuangan (SAK). Sehingga nantinya di ketahui perbandingan antara penerapan akuntansi lingkungan yang berdasarkan SAP dan SAK

\section{DAFTAR PUSTAKA}

Desi, Heni. 2011. Evaluasi Sistem Manajemen Pengelolaan Limbah Rumah Sakit. Jakarta.

Hansen, R dan M. Mowen. 2005. Management Accounting. $7^{\text {th }}$ Edition. Diterjemahkan oleh Dewi Fitriasari dan Deny Arnos Kwary. Jakarta : Salemba Empat.

Harahap, Sofyan Safri. 1995. Teori Akuntansi. Jakarta: PT. Raja Grafindo Persada

Hadi. 2012. Analisis penerapan Akuntansi Lingkungan pada PT. Istana Cipta Sembada. Banyuwangi

Ikatan Akuntan Indonesia. 2009. Standar Akuntansi Keuangan. Jakarta : Penerbit Salemba Empat

Ikhsan, Arfan. 2008. Akuntansi Lingkungan. Yogyakarta : Graha Ilmu Ikhsan, Arfan. 2009. Akuntansi Manajemen Lingkungan. Yogyakarta : Graha Ilmu Indriyanto, Supomo 2002 : Jurnal Akuntansi \& Investasi, Jurusan Akuntansi FE UMY. 2002 Metodologi Penelitian Bisnis untuk Akuntansi dan Manajemen. Edisi Pertama. Yogyakarta : BPFE

Kusumawati, Titik. 2014. Perlakuan Akuntansi Atas Pengelolaan limbah Pada RSUD Dr. R. Koesma Tuban. Surabaya.

Mathew dan Parrera, 1996. Enfiroman Accunting. Jakarta. 
Novia Rustika, 2010. Analisa Penerapan Akuntansi Lingkungan di Rumah Sakit Khusus Daerah Ibu dan Anak Siti Fatimah.

Nilasari, Fitri. 2014. Analisis Penerapan Akuntansi Lingkungan Terhadap Pengelolaan Limbah PG Djatiroto. Surabaya

Noviani, Aminah. 2014. Analisis Penerapan Akuntansi Lingkungan di Rumah Sakit Mardi Waluyo Metro. Indonesia

Pernyataan Standar Akuntansi Keuangan No. 33 Tahun 2014 Tentang Penyertaan biaya - biaya lain seperti biaya lingkungan.

Shela, dkk. 2014. Evaluasi Penerapan Akuntansi Manajemen Lingkungan pada PT II. Surabaya.

Sekaran, Uma. 2009. Metodologi Penelitian untuk Bisnis, Buku 1. Jakarta : Salemba Empat.

Susenohaji. 2002. Enviromental Management Accounting (EMA) : memposisikan kembali biaya lingkungan sebagai Informasi Strategis bagi Manajemen.

Suwardjono. 2005. Teori Akuntansi : Perekayasaan Pelaporan Keuangan. Edisi III. Yogyakarta : BPFE

Undang - Undang No. 32 Tahun 2009 Tentang Perlindungan dan Pengelolaan Lingkungan Hidup.

Undang - Undang No. 25 Tahun 2007 Tentang Penanaman Modal.

PP No. 24 Tahun 2005 Tentang Standar Akuntansi Pemerintahan No. 01

Pemendragi No. 64 Tahun 2013 Tentang Penerapan Akuntansi Berbasis Akrual 